\title{
Linking the spatial patterns of organisms and abiotic factors to ecosystem function and management: Insights from semi-arid environments
}

\author{
F. T. Maestre
}

Maestre, F. T. 2006. Linking the spatial patterns of organisms and abiotic factors to ecosystem function and management: Insights from semi-arid environments - Web Ecol. 6: 75-87.

Numerous theoretical and modeling studies have demonstrated the ecological significance of the spatial patterning of organisms on ecosystem functioning and dynamics. However, there is a paucity of empirical evidence that quantitatively shows how changes in the spatial patterns of the organisms forming biotic communities are directly related to ecosystem structure and functioning. In this article, I review a series of experiments and observational studies conducted in semi-arid environments from Spain (degraded calcareous shrubland, steppes dominated by Stipa tenacissima, and gypsum shrublands) to: 1) evaluate whether the spatial patterns of the dominant biotic elements in the community are linked to ecosystem structure and functioning, and 2) test if these patterns, and those of abiotic factors, can be used to improve ecosystem restoration. In the semiarid steppes we found a significant positive relationship between the spatial pattern of the perennial plant community and: i) the water status of $S$. tenacissima and ii) perennial species richness and diversity. Experimental plantings conducted in these steppes showed that $S$. tenacissima facilitated the establishment of shrub seedlings, albeit the magnitude and direction of this effect was dependent on rainfall conditions during the first yr after planting. In the gypsum shrubland, a significant, direct relationship between the spatial pattern of the biological soil crusts and surrogates of ecosystem functioning (soil bulk density and respiration) was found. In a degraded shrubland with very low vegetation cover, the survival of an introduced population of the shrub Pistacia lentiscus showed marked spatial patterns, which were related to the spatial patterns of soil properties such as soil compaction and sand content. These results provide empirical evidence on the importance of spatial patterns for maintaining ecosystem structure and functioning in semi-arid ecosystems. Furthermore, they show how taking into consideration the small-scale spatial patterns of organisms and abiotic factors, their restoration can be improved.

F. T. Maestre (fernando.maestre@urjc.es), Area de Biodiversidad y Conservación, ESCET, Universidad Rey Juan Carlos, C/ Tulipán s/n, ES-28933 Móstoles, Spain. 
The presence of non-random patterns in the spatial distribution of organisms is the norm, rather than the exception, in most natural, semi-natural and human-dominated ecosystems (Perry 1995, Dale 1999, Perry et al. 1999, Webster and Boag 1992, Grundmann and Debouzie 2000). These patterns are determined by a combination of processes that include environmental heterogeneity (Ehrenfeld et al. 1997), biotic interactions (Callaway 1995), patterns of growth and propagule dispersal (Lechowicz and Bell 1991), availability of "safe sites" for establishment (Harper et al. 1965), and random factors (Halpern 1988). The understanding of these patterns is one of the core objectives of ecology as a science; therefore, it is not surprising that spatial pattern analysis has received substantial attention by ecologists in the last decades, and that numerous methods for quantifying spatial patterns have been developed (Dale 1999, Perry et al. 2002).

Research on the spatial patterns of organisms has not been limited to describe them and to infer the underlying formative processes. In recent decades there has been a growing body of theoretical and modeling studies highlighting the importance of the spatial patterns of organisms per se (i.e. independently of co-occurring community attributes such as cover, species richness and evenness) as drivers of ecosystem functioning, stability and dynamics (Pacala and Deutschman 1995, Tilman and Kareiva 1997, Bolker et al. 2003). However, and despite their recognized importance, relatively few studies have empirically examined how these patterns alter phenomena such as individual performance, population dynamics, species coexistence, and community structure (Schmid and Harper 1985, Bergelson 1990, Stoll and Prati 2001, Tirado and Pugnaire 2003, Monzeglio and Stoll 2005). Furthermore, even fewer studies have evaluated whether these spatial patterns are directly related to ecosystem functioning in natural communities (Pacala and Deutschman 1995, Maestre et al. 2005a, Kikivdze et al. 2005).

Being a priority in land management in a wide variety of biomes, the restoration of degraded ecosystems is especially important in arid and semi-arid areas, which are being degraded and desertified at a fast rate throughout the globe (Kassas 1995, Le Houérou 1996, Reynolds and Stafford Smith 2002, Reynolds et al. 2005). Despite the specific objectives of their restoration may differ depending on the degree of degradation, and on climatic, biotic and socio-economic constraints, restoration programs often aim to increase plant cover by directly introducing plant individuals, primarily woody species (Whisenant 1999, Pausas et al. 2004, Maestre and Cortina 2004a). This management action is crucial to stop further degradation, to combat desertification and to foster the recovery of the structure, composition and function of degraded ecosystems in these areas (Gao et al. 2002, Maestre and Cortina 2004b, Bastida et al. 2006). The importance of restoration programs is likely to increase in the near future due to their potential to fix atmospheric $\mathrm{CO}_{2}$ and to reduce its concen- tration at a global scale (Keller and Goldberg 1998, Lal 2001).

The successful establishment of vegetation during the restoration of degraded arid and semi-arid areas is a challenging task due to the harsh climatic conditions, to the low soil resource levels, and to the scarce and unpredictable rainfall regimes that characterize these environments (Whisenant 1999). Important research efforts have been devoted in the last decades to overcome these limitations, and nowadays there are numerous techniques to aid plant establishment during restoration of arid and semi-arid environments (see Cortina et al. 2004 and Pausas et al. 2004 for reviews). Surprisingly, the use of the own spatial patterns of existing organisms and abiotic factors has often been neglected during the restoration of these areas (Padilla and Pugnaire 2006). Despite important floristic differences between regions, the physiognomy of semi-arid vegetation typically consist on a two-phase mosaic of discrete plant patches embracing different functional types - typically shrubs, perennial grasses and trees - surrounded by a bare ground matrix (Valentin et al. 1999). This spatial patterning is essential to maintain ecosystem composition and function (Noy Meir 1973, Tongway et al. 2004), and, indeed, is often a useful indicator of ecosystem degradation in arid and semi-arid areas (Wu et al. 2000, Bastin et al. 2002, Maestre and Cortina 2004b).

In this article I briefly review the results of a series of observational and experimental studies conducted over the last decade in three representative ecosystems of semi-arid areas of Spain: Stipa tenacissima steppes, gypsum outcrops dominated by biological soil crusts and degraded shrublands with very low perennial plant cover. These studies aimed to answer three basic questions: i) Is the spatial pattern of a community per se important as a driver of ecosystem structure and functioning?, ii) Can plant-plant interactions be employed to improve plant establishment during restoration?, and iii) Does the small-scale spatial pattern of abiotic factors determine the outcome of restoration actions? I do not intend to provide a comprehensive review of all the relevant research conducted on these topics, which have received considerable attention by ecologists and restoration practitioners in recent years. I rather aim to illustrate the relevance of the spatial pattern of organisms and abiotic factors for maintaining ecosystem structure/functioning and for improving restoration actions in semi-arid areas.

\section{Ecosystem structure and the spatial pattern of Stipa tenacissima in semi- arid steppes}

Stipa tenacissima L. steppes are one of the most important vegetation types in the driest areas of the Western Mediterranean Basin, where they cover $28000 \mathrm{~km}^{2}$ in Northern 
Africa (from Lybia to Morocco) and in the Iberian Peninsula (Le Houérou 2001). In their present state, these steppes are the result of a long-term human use of wooded steppes that included cutting, burning, fiber-cropping and overstocking, followed by abandonment (Cortina et al. 2007). The fiber from $S$. tenacissima has great strength and flexibility, and has been used to make ropes, sandals, baskets, mats, and other durable articles, and to produce high quality paper for centuries (Barber et al. 1997). In Spain there are historical records on the use of $S$. tenacissima by humans as early as $3500 \mathrm{BC}$. The intensification on its use started during the occupation of the Iberian Peninsula by the Carthaginians ( $480 \mathrm{BC}$ ) and, with differences in the intensity of this use over different historical periods, lasted until the 1960's (Barber et al. 1997). Because these activities, open shrublands containing $S$. tenacissima but dominated by species like Pinus halepensis Miller, Quercus coccifera L. and Pistacia lentiscus L. may have been degraded to S. tenacissima steppes, eventually supporting remnant shrub fragments (Cortina et al. 2007, Maestre and Cortina 2005).
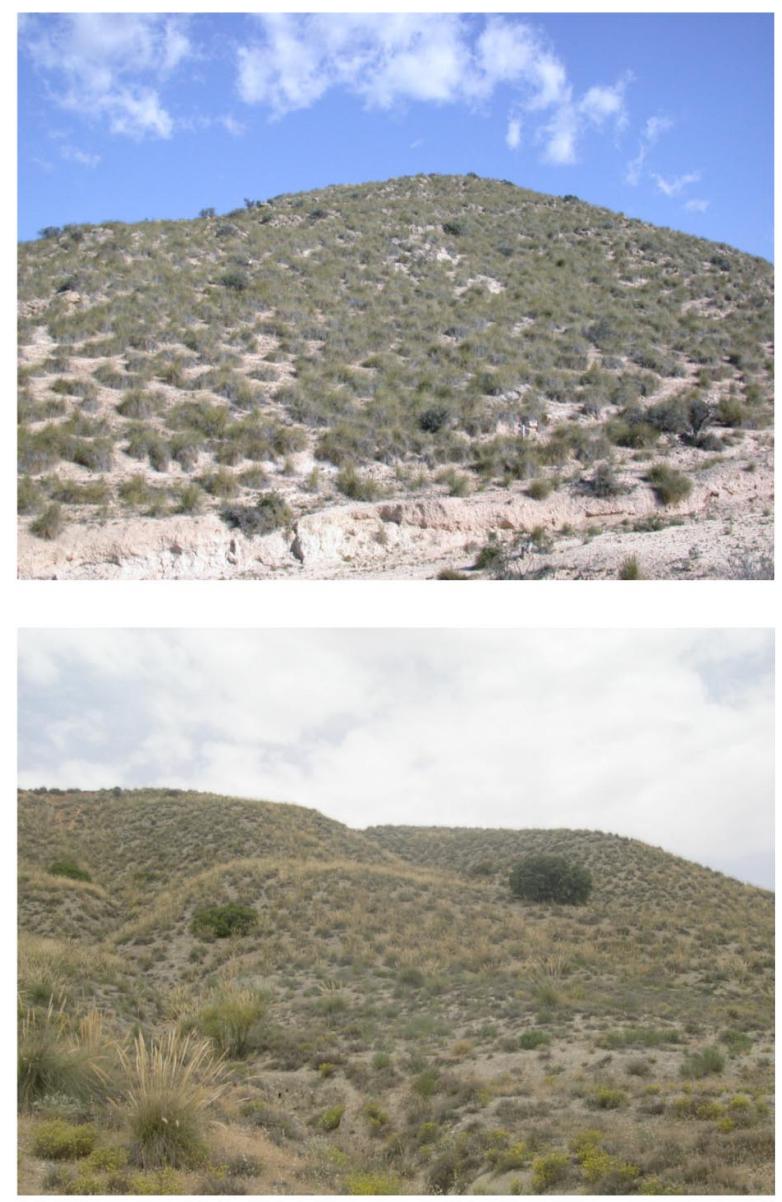

Despite the long-lasting human activities that took place in S. tenacissima steppes are still influencing aspects of the composition and structure in these ecosystems, such as species richness and diversity (Maestre 2004), it must be noted that direct plantings of tussocks were not widespread (Yanes 1993, Barbet et al. 1997). Nowadays, most S. tenacissima steppes are commonly structured in a spotted or banded spatial configuration, with vegetation patterns resembling features of the "tiger-bush" vegetation described for semi-arid regions throughout the world (Fig. 1). It has been shown that these patterns are largely controlled by topography and the associated runoff fluxes (Sánchez 1995, Puigdefábregas et al. 1999). Thus, on moderate slopes and at the cachtment scale, $S$. tenacissima tussocks tend to be aligned parallel to the contours to maximize their ability to trap runoff water generated in the bare ground areas during storm events (Puigdefábregas and Sánchez 1996, Webster and Maestre 2004, Maestre et al. 2005b). These inputs are critical for S. tenacissima growth (Puigdefábregas et al. 1999), and are also affected by the soil surface conditions in these areas (Cerdà 1997,
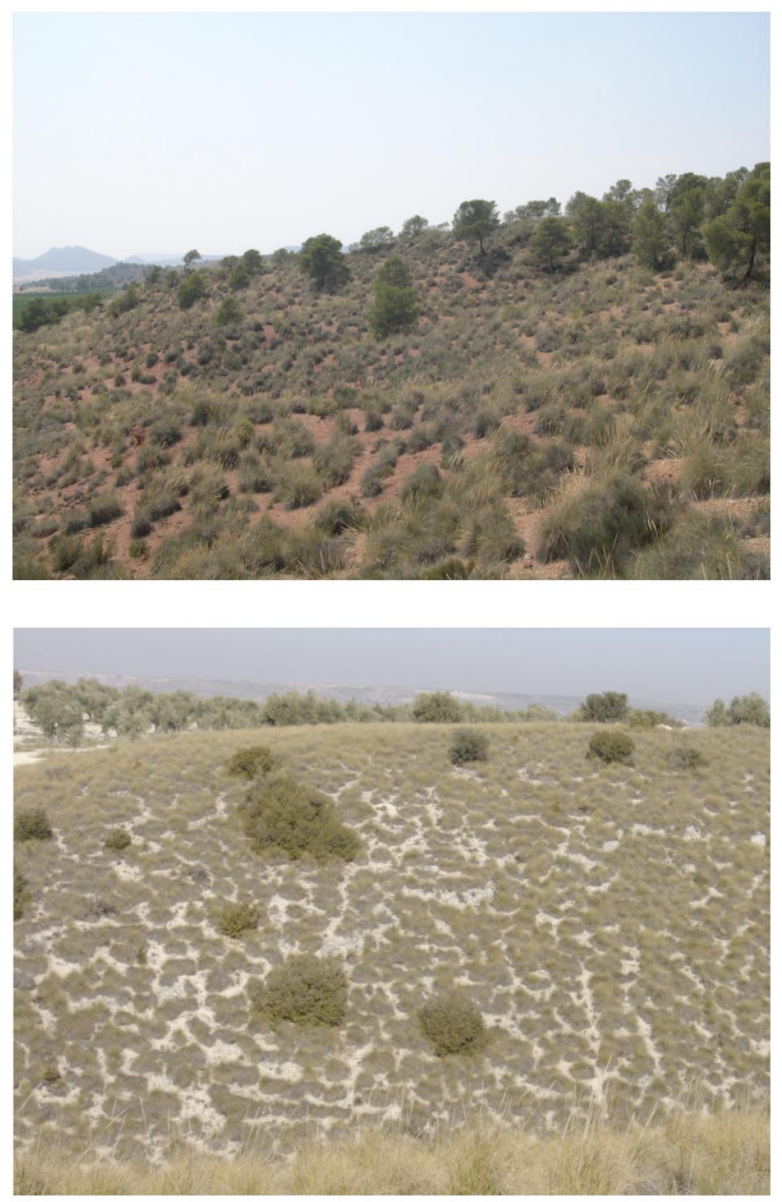

Fig. 1. View of different Stipa tenacissima steppes from Central and South-East Spain, showing the typical two-phase mosaic of bare ground areas and S. tenacissima tussocks and the presence of sprouting shrubs such as Quercus coccifera and trees like Pinus halepensis. 
Maestre et al. 2002a), and by attributes of discrete plant patches such as cover and spatial pattern (Imeson and Prinsen 2004, Cammeraat 2004).

In a recent study conducted in 15 steppe sites of SE Spain, Maestre and Cortina (2006) evaluated the effects of different ecosystem attributes -14 abiotic and biotic variables ranging from climatic to structural attributes of the vegetation - on the $\delta^{13} \mathrm{C}$ of $S$. tenacissima, a surrogate of its water use efficiency (Lathja and Milchener 1994). These authors found that the $\delta^{13} \mathrm{C}$ of $S$. tenacissima leaves was negatively related to its cover and positively related to the spatial pattern of perennial vegetation (Fig. 2a, b). The former relationship may be the result of the effects of perennial plant cover on the nutrient status of $S$. tenacissima. The $\delta^{13} \mathrm{C}$ of $S$. tenacissima leaves increased with increases in their $\mathrm{N}$ concentration (Fig. 2c), which was indeed negatively related to perennial plant cover (Fig. 2d). The effect of total cover on the nutrient status of $S$. tenacissima sug- gests the presence of intra- and inter-specific competition for belowground resources, a process already demonstrated in other steppes of SE Spain (Armas 2003, Ramírez 2006). Interestingly, the spatial pattern of perennial vegetation was not related to either total plant cover $(r=-0.371, p=$ $0.173, \mathrm{n}=15)$ or leaf $\mathrm{N}$ concentration $(\mathrm{r}=0.435, \mathrm{p}=$ $0.134, \mathrm{n}=15)$. Therefore, the positive relationship between the $\delta^{13} \mathrm{C}$ of $S$. tenacissima and the former variable suggests that an increase in the spatial aggregation of perennial vegetation, independently of its density, promotes an increase in the water use efficiency of this species. Albeit the Maestre and Cortina (2006) study cannot provide a full understanding of the mechanisms underlying the relationships observed, their results provide empirical evidence showing that the spatial pattern of vegetation per se may influence its own water use.

In a series of 17 steppe sites located along a degradation gradient in SE Spain, Maestre and Cortina (2004b) found
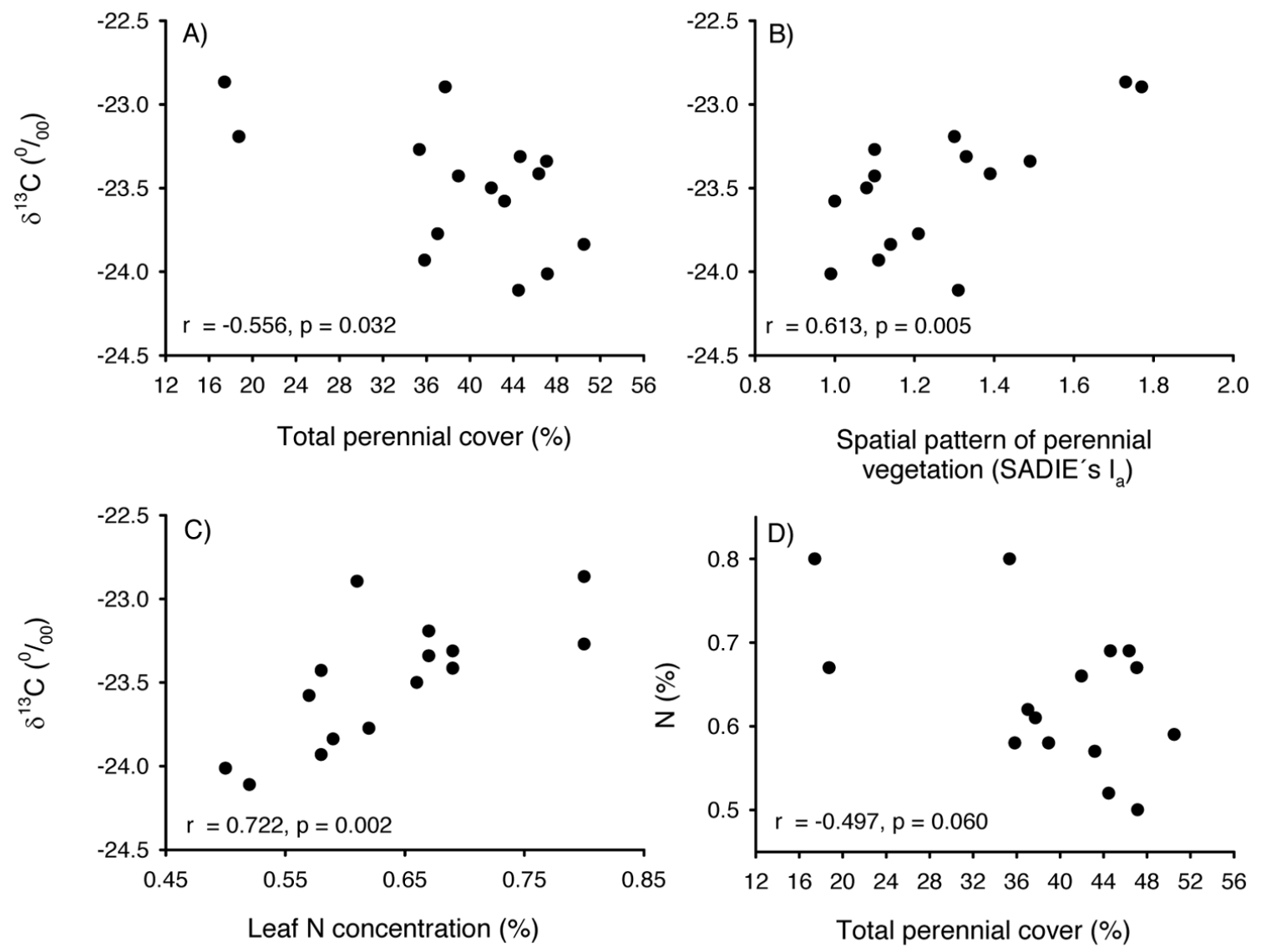

Fig. 2. Relationships between the $\delta^{13} \mathrm{C}$ of Stipa tenacissima and total perennial plant cover (A), the spatial pattern of perennial vegetation (B) and leaf $\mathrm{N}$ content (C), and between total plant cover and leaf $\mathrm{N}$ content (D). Plant spatial patterns were measured using SADIE analysis (Perry et al. 1999), in 15 steppes from SE Spain. As $I_{a}$ increases, the spatial pattern of vegetation becomes more aggregated. Results of correlation analyses (Pearson correlation coefficient) are also shown. Adapted from data presented in Maestre and Cortina (2006). 

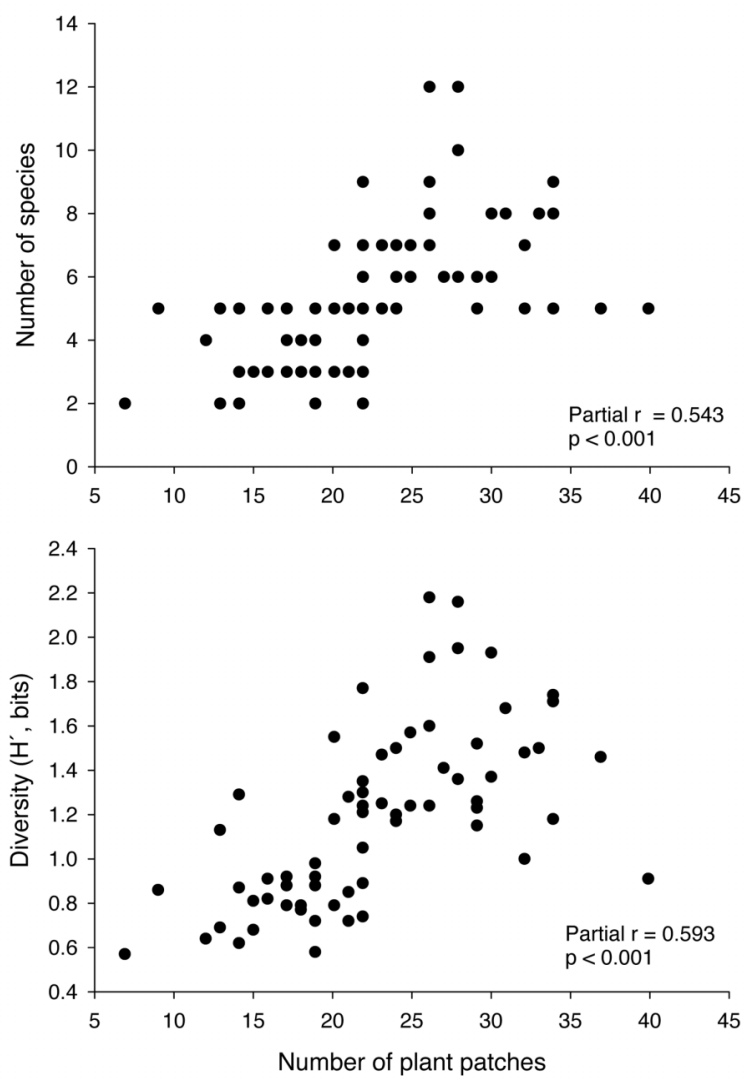

Fig. 3. Relationships between the number of discrete plant patches and the richness and diversity of perennial vascular plants in semi-arid steppes of SE Spain. Results of partial correlation analyses, where the effect of plant cover is controlled, are shown in the lower right margin of each graph. Adapted from data summarized in Maestre and Cortina (2004b).

a strongly significant and positive relationship between the number of discrete plant patches ( $S$. tenacissima constituted between the $38 \%$ and $94 \%$ of the total plant cover) - a simple indicator of the spatial patterning of vegetation and both the number and diversity of perennial plant species in $30 \mathrm{~m}$-long transects (Fig. 3). This relationship, which was maintained even when controlling for plant cover - a key vegetation attribute that could confound it -, indicates that the spatial patterning of $S$. tenacissima tussocks is an important attribute for maintaining the structure of these ecosystems.

Positive effects of $S$. tenacissima tussocks on the diversity and richness of vascular plants in semi-arid steppes may be related to facilitative processes mediated by their effects on microclimate and soil properties. Recent studies have thoroughly described the effect of these tussocks on their own microenvironment through microclimatic amelioration (Maestre et al. 2001, 2003a), the improvement in the soil structure and depth (Bochet et al. 1999, Puigdefábregas et al. 1999), and the increase in soil moisture (Puigdefábregas and Sánchez 1996, Maestre et al. 2001), water infiltration (Cerdà 1997, Maestre et al. 2002a), and carbon storage and nitrogen (Martínez-Sánchez et al. 1994, Sánchez 1995, Bochet et al. 1999) in relation to adjacent areas devoid of vascular plants. Therefore, $S$. tenacissima creates the so-called "resource islands" (Reynolds et al. 1999), a phenomenon commonly described in shrub species from arid and semi-arid areas throughout the world (Whitford 2002).

Through the creation of resource islands, S. tenacissima modifies the small-scale distribution and performance of a wide variety of taxa. In semi-arid steppes of SE Spain, Maestre (2003a, b) and Maestre et al. (2002a) have described how $S$. tenacissima tussocks modify the small-scale spatial patterning of soil lichens, cyanobacteria and mosses, with mosses dominating in the vicinity of the tussocks and cyanobacteria and lichens dominating the bare ground areas located between them. Interestingly, a significant negative relationship between the cover of cyanobacteria, which dominate bare-ground areas, and the infiltration rate was found (Maestre et al. 2002a), suggesting that the effect of $S$. tenacissima on these organisms could modify the source-sink process described above on its own benefit. Regarding vascular plants, it has been found that the vicinity of $S$. tenacissima tussocks holds more diversity and abundance of annual plants than the adjacent open ground areas (Sánchez 1995). Observational studies have reported positive spatial interactions between the spatial patterns of $S$. tenacissima and those of species such as $A n$ thyllis cytisoides (Webster and Maestre 2004, Maestre et al. 2005b), as well as higher survival of seedlings and adults of woody species in the vicinity of $S$. tenacissima tussocks than in open ground areas (García-Fayos and Gasque 2002). The implications of plant-plant interactions involving S. tenacissima for the restoration and management of these ecosystems will be discussed below.

\section{Biotic attributes and ecosystem functioning in communities dominated by biological soil crusts}

Biological soil crusts (BSC), composed of bacteria, cyanobacteria, algae, mosses, liverworts, fungi and lichens, are a major biotic component of arid and semi-arid ecosystems world-wide (West 1990, Belnap and Lange 2001). These crusts frequently cover soil surfaces (Fig. 4) and exert a strong influence on critical ecosystem processes like infiltration, carbon sequestration and nutrient cycling (Beymer and Klopatek 1991, Evans and Ehleringer 1993). They also influence the distribution and abundance of plants and animals (Prasse and Bornkamm 2000, DeFalco et al. 2001, Shepherd et al. 2002). Despite important advances in our knowledge of the structure, composition, physiology and biogeography of biological soil crusts (reviewed by Belnap \& Lange 2001), little is known on the 
A)

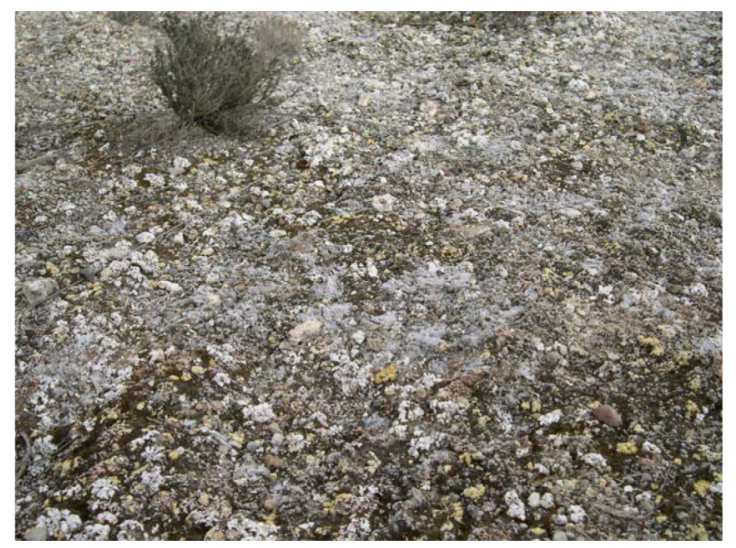

B)

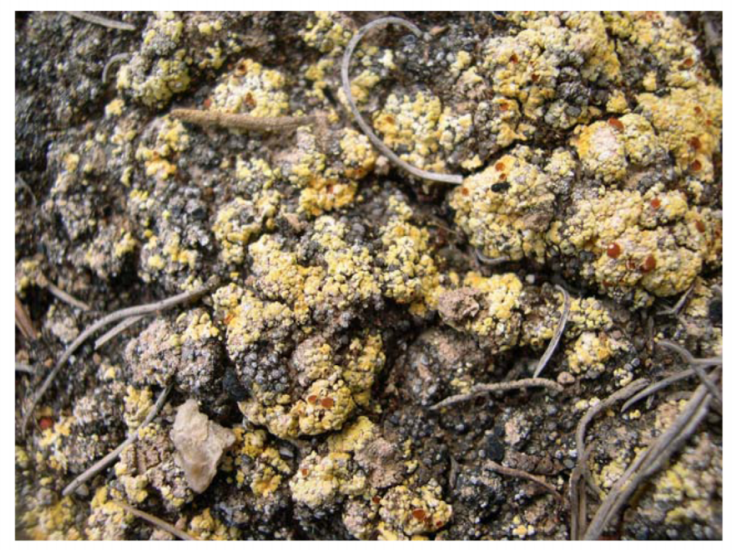

Fig. 4. A) View of biological soil crusts dominating the spaces between plants in non-disturbed gypsum outcrops from central Spain, B) Close up view of the lichens forming the crust; the main species in this picture are Fulgensia subbracteata (yellow thalli) and Toninia sedifolia (grey and black thalli).

effects of small-scale habitat variation on the spatial patterns of their components (Maestre 2003a, b, Martínez et al. 2006), and on the influence of these patterns on ecosystem functioning.

In a recent study, Maestre et al. (2005a) related biotic attributes of BSC (spatial pattern, cover, species richness and species evenness) to different surrogates of ecosystem functioning (total $\mathrm{C}$ and $\mathrm{N}$, aggregate stability, bulk density and soil respiration) using structural equation modeling in two study sites located in central and SE Spain. Both the biotic attributes of BSC and the surrogates of ecosystem functioning showed an important degree of variation within the studied areas (Maestre et al. 2005a, Martínez et al. 2006). In the site located in Alicante, spatial pattern was positively and directly related to respiration, and negatively related to soil bulk density (Fig. 5). However, the magnitude of this relationship was lower than that between at- tributes such as cover and species richness on the same surrogates of ecosystem functioning. In the other site, spatial pattern was not significantly related to any of the surrogates of ecosystem functioning evaluated.

These results represent, to our knowledge, one of the first empirical evidences of a direct relationship between the spatial pattern of a community and surrogates of ecosystem functioning, and add new empirical evidence on the importance of the spatial pattern of a community as a driver of ecosystem functioning. They also suggest that this importance may depend on co-occurring community attributes like total cover and diversity.

\section{Small-scale spatial heterogeneity of soil properties and ecosystem restoration in degraded shrublands}

In semi-arid environments, germination and subsequent establishment of plants is strongly controlled by soil water availability (Veenendal et al. 1996, Escudero et al. 1999). This availability shows a strong degree of heterogeneity owing to large spatial and temporal variations in rainfall patterns (Le Houérou et al. 1988), and to complex spatial redistribution of rainwater once it arrives to the soil surface (Tongway and Ludwig 1994, Seghieri et al. 1997). Such redistribution is strongly influenced by soil surface properties like compaction, physical crusts and rock fragments, which have a prevailing role in runoff and infiltration dynamics in these areas (Valentin and Bresson 1992, Valentin 1994). Therefore, the spatial pattern of surface soil properties, which often is quite complex (Bromley et al. 1997, Seghieri et al. 1997, Maestre and Cortina 2002), should be critical for seedling establishment in semi-arid degraded areas holding a low vegetation cover.

In a recent study, Maestre et al. (2003b) evaluated the effects that the small-scale spatial patterns of abiotic factors had on the establishment of the shrub Pistacia lentiscus L. in a degraded area in Southeastern Spain. These authors randomly introduced a total of 205 one-year-old seedlings in a 0.28 -ha $(100 \mathrm{~m} \times 28 \mathrm{~m})$ experimental plot apparently homogeneous, and followed seedling survival during the three years after planting. After this time, only $36 \%$ of the seedlings survived. This mortality did not occur randomly throughout the plot, as clearly defined areas of high and low survival emerged after the first summer in the field (Fig. 6). Surface soil variables showed complex small-scale spatial patterns in the studied plot. Interestingly, variables such as bare soil cover, sand content, and soil compaction were strongly and significantly related to seedling survival, suggesting that the small-scale pattern of these variables controlled the spatial pattern of seedling survival (Fig. 7, Maestre et al. 2003b).

These results have strong implications to improve the restoration of degraded semi-arid ecosystems. Attempts to 


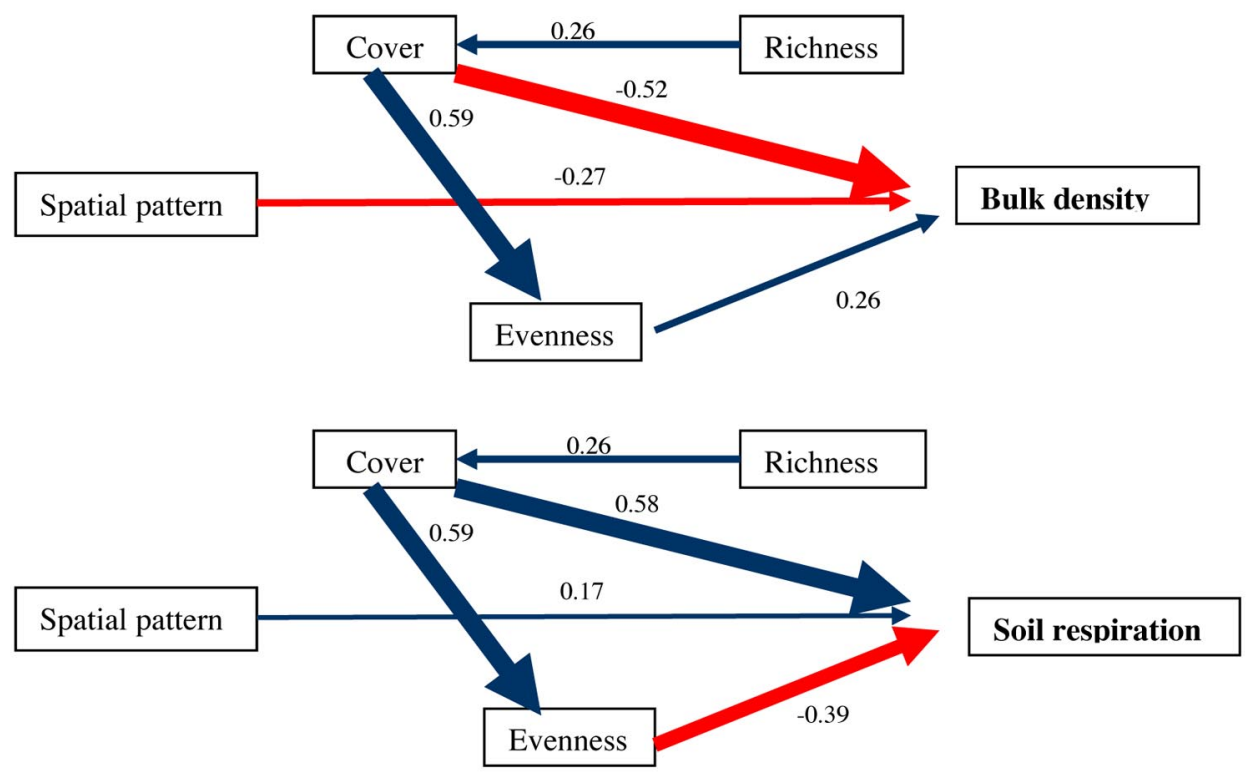

Fig. 5. Structural model showing the relationships between the attributes of biological soil crusts and different surrogates of ecosystem functioning in a gypsum area from Alicante (SE Spain). Only significant paths are shown. The breadth of the arrow is proportional to the standardized path coefficient, which is indicated by the corresponding number. Positive and negative relationships are in blue and red, respectively. Adapted from Maestre et al. (2005a).

restore them with plantings of woody species using regular grids have been often ineffective (Maestre and Cortina 2004a). Against uniform plantings, restoration of these areas should be based on the introduction of vegetation according to natural vegetation patterns, with the aim of recover previous landscape processes (Ludwig et al. 1999). Such restoration efforts can be improved by incorporating knowledge on the spatial pattern of those soil properties affecting seedling establishment. Areas of potential high mortality could be defined beforehand by performing an analysis of the spatial distribution of those variables more related with seedling survival before planting. Alternatively, the results presented suggest that restoration success could be improved reducing the amount of bare soil cover at the moment of planting, something that can be easily and cheaply done by placing stones or branches over the surface of the planting hole.

\section{Plant-plant interactions and ecosystem restoration in Stipa tenacissima steppes}

As mentioned above, S. tenacissima steppes derive from the degradation of open shrublands and woodlands by human activities carried out during centuries. Remnants of native, late-successional, sprouting shrubs like Pistacia lentiscus L. and Quercus coccifera L. play key functional and structural roles in semi-arid S. tenacissima steppes from SE Spain. They enhance ecosystem functioning (Maestre and Cortina 2004b), are a major determinant of plant diversity (Maestre 2004, Maestre and Cortina 2005), and supply shelter and food for wild and game animals (López and Moro 1997). Stipa tenacissima steppes are often degraded through their distribution range in SE Spain (Maestre and Cortina 2004b), and increasing shrub cover and density in these ecosystems through direct planting is often a target objective when restoring them (Cortina et al. 2007).

While facilitation has been documented in a wide variety of environments (Callaway 1995), it is by far most common in arid and semi-arid ecosystems (Flores and Jurado 2003). Despite the a priori potential and attractiveness of facilitation as a restoration tool, and the large number of studies emphasizing its importance as a driver of community structure and ecosystem dynamics, it has been largely neglected in the restoration projects carried out in semi-arid areas for decades (Padilla and Pugnaire 2006).

The spatial patterning of $S$. tenacissima tussocks modifies the distribution of soil properties and microclimatic conditions, and observational studies suggest that these changes may facilitate the establishment of some BSC components and vascular plants. In order to evaluate the 


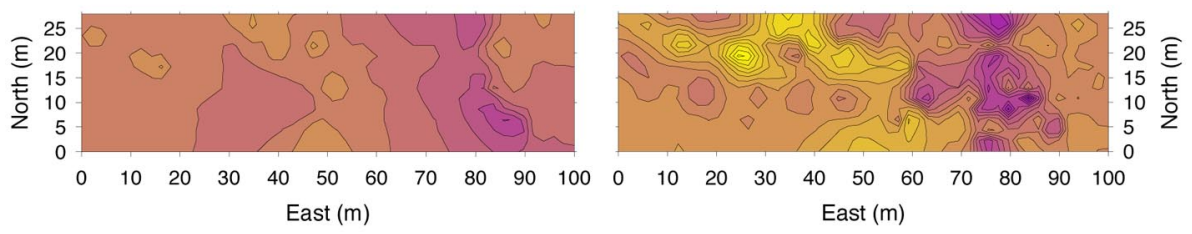

April $1998\left(I_{a}=1.35, \mathrm{p}=0.127\right) \quad$ November $1999\left(I_{a}=2.32, \mathrm{p}=0.001\right)$

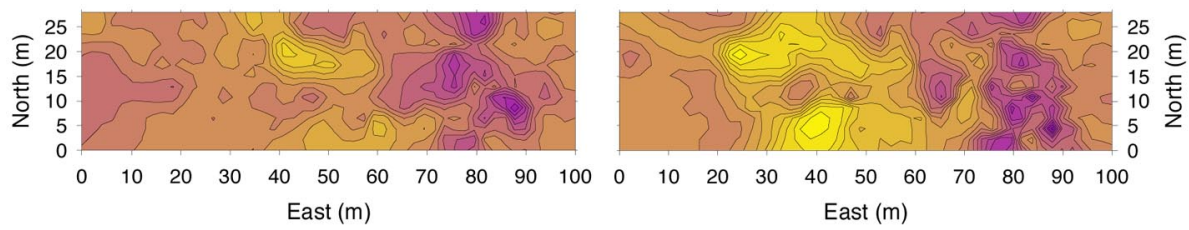

September $1998\left(I_{a}=1.84, \mathrm{p}=0.016\right) \quad$ September $2000\left(I_{a}=2.70, \mathrm{p}=0.001\right)$
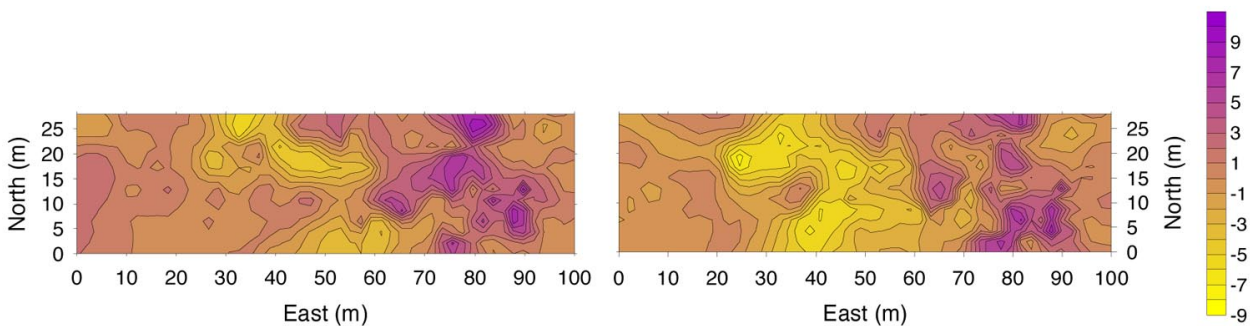

April $1999\left(I_{a}=2.15, \mathrm{p}=0.005\right)$

December $2000\left(I_{a}=2.69, \mathrm{p}=0.001\right)$

Fig. 6. Maps showing the small-scale spatial pattern of survival (estimated with the SADIE's index of aggregation, Perry et al. 1999) of 205 randomly-introduced Pistacia lentiscus seedlings in a $100 \times 28 \mathrm{~m}$ experimental area from SE Spain. The maps show the distribution and evolution of patches (high survival areas, in purple) and gaps (low survival areas, in yellow) during the three years after planting. Values of $I_{a}$ (SADIE's index of aggregation) significantly higher than 1 indicate that the overall spatial pattern of survival in the plot is aggregated. Adapted from Maestre et al. (2003b).

potential of these changes to improve the restoration of $S$. tenacissima steppes, a series of experimental plantings in steppes located in the province of Alicante (SE Spain) have been conducted (Table 1). In these experiments, seedlings of different shrub species were introduced under the canopy of $S$. tenacissima tussocks and in bare ground areas devoid of vascular plants. The results obtained were mainly dependent on the climatic conditions of the first year after plantation, the species considered and the presence of $S$. tenacissima. This species facilitated the establishment of the introduced seedlings in most cases where mortality was not complete. The amelioration of harsh climatic conditions through shade, as well as the increase in soil fertility, has been identified as the main drivers of this facilitation (Maestre et al. 2003a). However, this effect was not universal, and net competitive interactions between $S$. tenacissi$m a$ and the introduced seedlings were observed under low rainfall conditions. Similar results have been observed in semi-arid Pinus halepensis plantations when introducing shrubs like Pistacia lentiscus under the canopy of $P$. ha- lepensis and in the bare spaces between pines (Maestre and Cortina 2004a).

In semiarid steppes of SE Spain, it has been observed that $S$. tenacissima increases soil water availability after main rainfall events, and that this effect is maintained for some time thanks to the reduced evaporation caused by the shading of its canopy (Maestre et al. 2001, 2003a). However, and at the same time, manipulative experiments have demonstrated that competition for water between $S$. tenacissima and the introduced shrubs is intense (Maestre et al. 2003a). I argue that, in strongly water-limited environments, we should expect facilitation only when neighbors increase the water status of the target plant (the species being facilitated) when compared to bare ground areas without vegetation. As plant water status is strongly linked to the availability of water in the soil, it is likely that a threshold level in water availability will define the transition from net negative to net positive effects of $S$. tenacissi$m a$ on the introduced shrubs (Maestre and Cortina 2004c; Armas and Pugnaire 2005). 


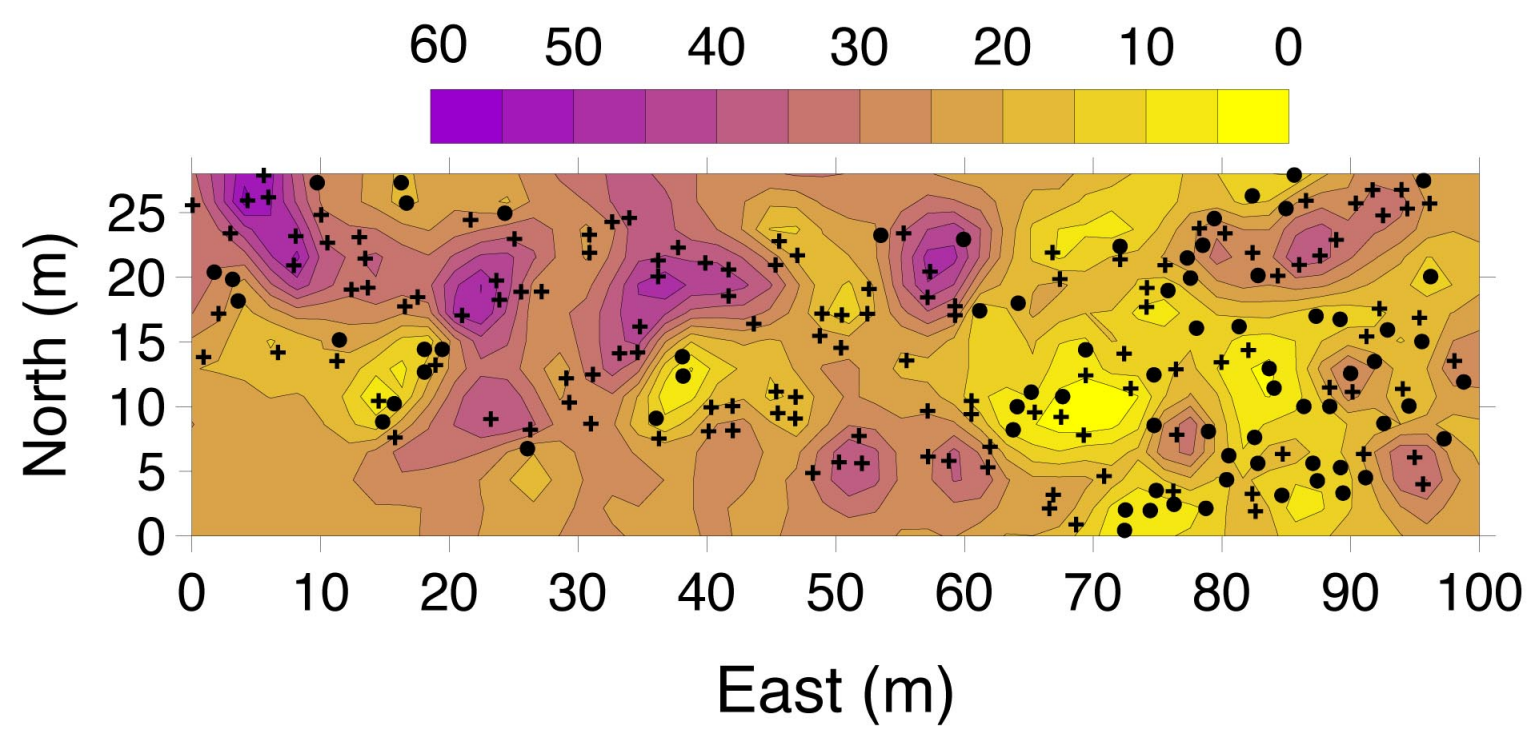

Fig. 7. Small-scale spatial distribution of the amount of bare soil covering planting holes (in $\%$ ) and of seedling survival three years after planting. Crosses $(+)$ and circles $(\bullet)$ are dead and alive seedlings, respectively. There is a significant negative relationship between the amount of bare soil and the survival of seedlings (logistic regression; $\mathrm{p}<0.001)$. Elaborated from Maestre et al. (2003b).

\section{Concluding remarks}

Spatial heterogeneity in the distribution of vegetation and soil resources is a hallmark of semi-arid ecosystems worldwide, and a large set of field studies have demonstrated that the spatial pattern of vegetation influence ecosystem structure and functioning through the formation of "resource islands" underneath the canopy of plant patches (see review by Whitford 2002). However, the relative importance of spatial pattern against other co-occurring community attributes as a driver of ecosystem functioning in these ecosystems is largely unknown. Using examples drawn from $S$. tenacissima steppes and BSC-dominated communities, I have illustrated that the spatial pattern per se of a biotic community is an important driver of ecosystem structure and functioning. However, major gaps in our knowledge of the functional role of spatial patterns remain. Two important steps towards filling them up would be the realization of: (i) cross-ecosystem studies to evaluate the generality of the results observed so far, and (ii) experiments manipulating in a factorial fashion the biotic attributes of communities (richness, diversity and spatial pattern).

Both the analysis of spatial pattern of those abiotic factors associated with mortality clumps and positive plant interactions have an enormous potential to improve the restoration of semi-arid degraded ecosystems, especially under conditions of moderate abiotic stress. Their use in restoration would allow to incorporate the own ecosystem structure and functional processes into their active man- agement, an issue as largely advocated by ecologists as rarely employed in practice (Wallace et al. 1980, Whisenant 1999). Both techniques have also ecological, economical and technical advantages against other techniques currently being recommended to restore degraded ecosystems in drylands (Cortina et al. 2004, Pausas et al. 2004). They do not require the use of heavy machinery, the purchase of special material (e.g. tree shelters) and the use of special nursery protocols (e.g. mycorrhizal inoculation, seedling preconditioning). They do not destroy existing vegetation, nor modify soil conditions and hydrological processes critical for proper ecosystem functioning (Ludwig et al. 2004), as techniques that employ heavy machinery do. When using facilitation as an aid in restoration, however, we must take into account that the rainfall registered during the first year after planting is critical for the success of plantations in semi-arid environments (Cortina et al. 2004), and that, under conditions of very low rainfall, neighbors may reduce, rather than enhance, the establishment of the introduced seedlings.

Advancing in our understanding of the functional role of the spatial pattern of biotic populations and communities, and of the abiotic factors driving them, will undoubtedly lead to the establishment of successful conservation, monitoring and restoration programs in semi-arid environments. The challenges of building the necessary bridges between scientists and land managers to incorporate this ecological knowledge into management practices are enormous, so is the need for urgent action to understand and manage semi-arid ecosystems worldwide. 
Table 1. Results of experimental plantings evaluating the effect of Stipa tenacissima on the survival of one-year-old seedlings of Mediterranean woody shrubs. In all cases, the seedlings were planted using hand-made $25 \times 25 \times 25 \mathrm{~cm}$ planting holes. YE = Planting year, SP = Species, SI = Name of the experimental site, ST = survival of seedlings planted in the vicinity of S. tenacissima tussocks (in \%), $\mathrm{SO}=$ survival of seedlings planted in open ground areas devoid of vascular plants (in \%), DU = duration of the study (in months), RA $=$ rainfall accumulated during the first year after planting $(\mathrm{mm}), \mathrm{SO}=$ source of data.

\begin{tabular}{|c|c|c|c|c|c|c|c|}
\hline YE & SP & SI & ST & $\mathrm{SO}$ & DU & RA & $\mathrm{SO}$ \\
\hline \multirow{9}{*}{1998} & Quercus coccifera & Aguas & 5 & 7 & 12 & 212 & \multirow{9}{*}{$\begin{array}{l}\text { Maestre et al. } \\
(2001)\end{array}$} \\
\hline & & Ballestera & 13 & 4 & 12 & 132 & \\
\hline & & Campello & 20 & 2 & 12 & 197 & \\
\hline & Pistacia lentiscus & Aguas & 10 & 3 & 12 & 212 & \\
\hline & & Ballestera & 16 & 15 & 12 & 132 & \\
\hline & & Campello & 17 & 9 & 12 & 197 & \\
\hline & Medicago arborea & Aguas & 85 & 78 & 12 & 212 & \\
\hline & & Ballestera & 69 & 30 & 12 & 132 & \\
\hline & & Campello & 85 & 77 & 12 & 197 & \\
\hline \multirow[t]{6}{*}{1999} & Quercus coccifera & Aguas & 0 & 0 & 12 & 264 & \multirow{6}{*}{$\begin{array}{l}\text { Maestre et al. } \\
(2002 b)\end{array}$} \\
\hline & & Ballestera & 0 & 0 & 12 & 150 & \\
\hline & & Campello & 0 & 0 & 12 & 193 & \\
\hline & Quercus coccifera* & Aguas & 0 & 0 & 12 & 264 & \\
\hline & & Ballestera & 0 & 0 & 12 & 150 & \\
\hline & & Campello & 0 & 0 & 12 & 193 & \\
\hline \multirow[t]{6}{*}{1999} & Quercus coccifera & Aguas & 0 & 0 & 24 & 264 & \multirow{6}{*}{$\begin{array}{l}\text { Maestre } \\
(2002)\end{array}$} \\
\hline & & Ballestera & 0 & 0 & 24 & 150 & \\
\hline & & Campello & 0 & 0 & 24 & 193 & \\
\hline & Pistacia lentiscus & Aguas & 8 & 6 & 24 & 264 & \\
\hline & & Ballestera & 0 & 3 & 24 & 150 & \\
\hline & & Campello & 3 & 0 & 24 & 193 & \\
\hline \multirow[t]{2}{*}{2001} & Pistacia lentiscus & Aguas & 57 & 32 & 15 & 225 & \multirow{12}{*}{$\begin{array}{l}\text { Maestre et al. } \\
(2003 a) \\
\text { Maestre et al. } \\
(2006)\end{array}$} \\
\hline & & Ballestera & 4 & 0 & 15 & 149 & \\
\hline \multirow[t]{10}{*}{2003} & Pistacia lentiscus $\dagger$ & Albatera & 0 & 0 & 17 & 133 & \\
\hline & & Jijona & 72 & 72 & 17 & 125 & \\
\hline & & Lanuza & 56 & 23 & 17 & 134 & \\
\hline & & Marquesa & 83 & 67 & 17 & 156 & \\
\hline & & Finestrat & 40 & 60 & 17 & 171 & \\
\hline & & Fontcalent & 47 & 88 & 17 & 109 & \\
\hline & & Palomaret & 13 & 0 & 17 & 139 & \\
\hline & & Peñarrubia & 0 & 0 & 17 & 187 & \\
\hline & & Relleu & 89 & 65 & 17 & 150 & \\
\hline & & Ventós & 0 & 0 & 17 & 102 & \\
\hline
\end{tabular}

* Seedlings inoculated with sporal inoculum of Pisolithus tinctorius in the nursery.

$\dagger$ Rainfall values from this experiment correspond to the first eight months after planting.

Acknowledgements - I would like to thank all the colleagues that have been involved in the research presented in this article for their collaboration and stimulating ideas throughout the years: Jordi Cortina, Susana Bautista, James F. Reynolds, Adrián Escudero, Isabel Martínez and César Guerrero. Nacho Querejeta clarified some points on the interpretation of stable isotope results, and Fernando Valladares, Ragan Callaway and Chris Lortie provided insightful comments and discussions on plant-plant interactions. Francisco Lloret and José $\mathrm{M}^{\mathrm{a}}$ Rey Benayas provided multiple comments that helped to improve the manuscript. This review was possible thanks to the support from a Ramón y Cajal contract funded by the Spanish Ministerio de Educación y Ciencia, from an Early Career Project Grant (ECPG 231/607) funded by the British Ecological Society, and from the Comunidad de
Madrid-funded projects REMEDINAL (S-0505/AMB/0335) and CEFEMED (URJC-RNT-063-2). The latter is also funded by Universidad Rey Juan Carlos.

\section{References}

Armas, C. 2003. Balance de la interacción entre plantas superiores en ambientes semiáridos: mecanismos y procesos. PhD. Thesis. Universidad Autónoma de Madrid.

Armas, C. and Pugnaire, F. I. 2005. Plant interactions govern population dynamics in a semi-arid plant community. - J. Ecol. 93: 978-989. 
Barber, A., Cabrera, M. R. and Guardiola, I. 1997. Sobre la cultura de l'espart al territori valencià. - Fundació Bancaixa, Valencia.

Bastida, F., Moreno, J. L., Hernández, T. et al. 2006. Microbiological activity in a soil 15 years after its devegetation. - Soil Biol. Biochem. 38: 2503-2507.

Bastin, G., Ludwig, J. A., Eager, R. W. et al. 2002. Indicators of landscape function: comparing patchiness metrics using remotely-sensed data from rangelands. - Ecol. Indicators 1: 243-260.

Belnap, J. and Lange, O. L. (eds). 2001. Biological Soil Crusts: Structure, Function, and Management. - Springer, Berlin.

Bergelson, J. 1990. Life after death: site pre-emption by the remains of Poa annua. - Ecology 71: 2157-2165.

Beymer, R. J. and Klopatek, J. M. 1991. Potential contribution of carbon by microphytic crusts in pinyon-juniper woodlands. - Arid Soil Res. Rehab. 5: 187-198.

Bochet, E., Rubio, J. L. and Poesen, J. 1999. Modified topsoil islands within patchy Mediterranean vegetation in SE Spain. - Catena 38: 23-44.

Bromley, J., Brouwer, J., Barker, A. P. et al. 1997. The role of surface water redistribution in an area of patterned vegetation in a semi-arid environment, south-west Niger. - J. Hydrol. 198: 1-29.

Bolker, B. M., Pacala, S. W. and Neuhauser, C. 2003. Spatial dynamics in model plant communities: What do we really know? - Am. Nat. 162: 135-148.

Callaway, R. M. 1995. Positive interactions among plants. - Bot. Rev. 61: 306-349.

Cammeraat, E. L. H. 2004. Scale dependent thresholds in hydrological and erosion response of a semi-arid catchment in southeast Spain. - Agric. Ecosystems Environ. 104: 317332.

Cerdà, A. 1997. The effect of patchy distribution of Stipa tenacissima L. on runoff and erosion. - J. Arid Environ. 36: 37-51.

Cortina, J., Bellot, J., Vilagrosa, A. et al. 2004. Restauración en semiárido. -In: R. Vallejo and J. A. Alloza (eds.), Avances en el Estudio de la Gestión del Monte Mediterráneo. Fundación CEAM, pp. 345-406.

Cortina, J., Maestre F. T. and Ramírez, D. 2007. Innovations in semiarid restoration. The case of Stipa tenacissima L. grass steppes. - In: S. Bautista, J. Aronson and R. Vallejo (eds.), Land Restoration to Combat Desertification: Innovative Approaches, Quality Control and Project Evaluation. Fundación Ceam, Valencia (in press).

Dale, M.R.T. 1999. Spatial Pattern Analysis in Plant Ecology. Cambridge University Press.

DeFalco, L. A., Detling, J. K., Richard Tracy, C. et al. 2001. Physiological variation among native and exotic winter annual plants associated with microbiotic crusts in the Mojave Desert. - Plant Soil 234: 1-14.

Ehrenfeld, J. G., Han, X., Parsons, W. F. J. et al. 1997. On the nature of environmental gradients. Temporal and spatial variability of soils and vegetation in the New Jersey Pineland. J. Ecol. 85: 785-798.

Escudero, A., Somolinos, R. C., Olano, J. M. et al. 1999. Factors controlling the establishment of Helianthemum squamatum, an endemic gypsophile of semi-arid Spain. - J. Ecol. 87: 290-302.

Evans, R. D. and Ehleringer, J. R. 1993. A break in the nitrogen cycle in aridlands? Evidence from $\delta^{15} \mathrm{~N}$ of soils. - Oecologia 93: 314-317.
Flores, J. and Jurado, E. 2003. Are nurse-protégé interactions more common among plants from arid environments? - J. Veg. Sci. 14: 911-916.

Gao, Y., Yu Quiu, G., Hideyuki, S. et al. 2002. A 10-Year Study on Techniques for Vegetation Restoration in a Desertified Salt Lake Area. - J. Arid Environ. 52: 483-497.

García-Fayos, P. and Gasque, M. 2002. Consequences of a severe drought on spatial patterns of woody plants in a two-phase mosaic steppe of Stipa tenacissima L. - J. Arid Environ. 52: 199-208.

Grundmann, G. L. and Debouzie, D. 2000. Geostatistical analysis of the distribution of $\mathrm{NH}_{4}^{+}$and $\mathrm{NO}_{2}^{-}$oxidizing bacteria and serotypes at the millimeter scale along a soil transect. FEMS Microbiol. Ecol. 34: 57-62.

Halpern, C. 1988. Early successional pathways and the resistance and resilience of forest communities. - Ecology 69: 17031715.

Harper, J. L., Williams, J. T. and Sagar, G. R. 1965. The heterogeneity of soil surfaces and its role in determining the establishment of plants from seed. - J. Ecol. 53: 273-286.

Imeson, A. C. and Prinsen, H. A. M. 2004. Vegetation patterns as biological indicators for identifying runoff and sediment source and sink areas for semi-arid landscapes in Spain. Agric. Ecosystems Environ. 104: 333-342.

Kassas M. 1995. Desertification: a general review. - J. Arid Environ. 30: 115-128.

Keller, A. A. and Goldstein, R. A. 1998. Impact of carbon storage through restoration of drylands on the global carbon cycle.Environ. Manage. 22: 757-766.

Kikivdze, Z., Pugnaire, F. I., Brooker, R. W. et al. 2005. Linking patterns and processes in alpine plant communities: a global study. - Ecology 86: 1395-1400.

Lal, R. 2001. Potential of desertification control to sequester carbon and mitigate the greenhouse effect. - Clim. Change 51: 35-72.

Lajtha, K. K. and Michener, R. H. (eds.). 1994. Stable Isotopes in Ecology and Environmental Science. - Blackwell, Cambridge.

Lechowicz, M. J. and Bell, G. 1991. The ecology and genetics of fitness in forest plants, part 2. Microspatial heterogeneity of the edaphic environment. - J. Ecol. 79: 687-696.

Le Houérou, H. N., Bingham, R. L., and Skerbek, W. 1988. Relationship between the variability of primary production and the variability of annual precipitation in world arid lands. $-\mathrm{J}$. Arid Environ. 15: 1-18.

Le Houérou, H. N. 1996. Climate change, drought and desertification. - J. Arid Environ. 34: 133-185.

Le Houérou, H. N. 2001. Biogeography of the arid steppeland north of the Sahara. - J. Arid Environ. 48: 103-128.

López, G. and Moro, M. J. 1997. Birds of Aleppo pine plantations in south-east Spain in relation to vegetation composition and structure. - J. Appl. Ecol. 34: 1257-1272.

Ludwig, J. A., Tongway, D. J. and Marsden, S. G. 1999. Stripes, strands or stripples: modelling the influence of three landscape banding patterns on resource capture and productivity in semi-arid woodlands, Australia. - Catena 37: 257-273.

Ludwig, J. A., Tongway, D. J., Bastin, G. et al. 2004. Monitoring ecological indicators of rangeland functional integrity and their relation to biodiversity at local to regional scales. - Austral Ecol. 29: 108-120.

Maestre, F. T. 2003a. Small-scale spatial patterns of two soil lichens in semi-arid Mediterranean steppe. - Lichenologist 35: 71-81. 
Maestre, F. T. 2003b. Variaciones en el patrón espacial a pequeña escala de los componentes de la costra biológica en un ecosistema mediterráneo semiárido. - Rev. Chil. Hist. Nat. 76: $35-46$.

Maestre, F. T. 2004. On the importance of patch attributes, abiotic factors and past human impacts as determinants of plant species richness and diversity in Mediterranean semi-arid steppes. - Divers. Distrib. 10: 21-29.

Maestre, F. T. and Cortina, J. 2002. Spatial patterns of surface soil properties and vegetation in a Mediterranean semi-arid steppe. - Plant Soil 241: 279-291.

Maestre, F. T. and Cortina, J. 2004a. Are Pinus halepensis plantations useful as a restoration tool in degraded semi-arid Mediterranean areas?. - For. Ecol. Manage. 198: 303-317.

Maestre, F. T. and Cortina, J. 2004b. Insights into ecosystem composition and function in a sequence of degraded semiarid steppes. - Restor. Ecol. 12: 494-502.

Maestre, F. T. and Cortina, J. 2004c. Do positive interactions increase with abiotic stress? A test from a semi-arid steppe. Proc. R. Soc. Lond. B (Suppl.) 271: S331-S333.

Maestre, F. T. and Cortina, J. 2005. Remnant shrubs in Mediterranean semi-arid steppes: effects of shrub size, abiotic factors and species identity on understorey richness and occurrence. - Acta Oecol. 27: 161-169.

Maestre, F. T. and Cortina, J. 2006. Ecosystem structure and soil surface conditions drive the variability in foliar $\delta^{13} \mathrm{C}$ and $\delta^{15} \mathrm{~N}$ of Stipa tenacissima in semi-arid Mediterranean steppes. - Ecol. Res. 21: 44-53.

Maestre, F. T., Bautista, S., Cortina, J. et al. 2001. Potential of using facilitation by grasses to establish shrubs on a semi-arid degraded steppe. - Ecol. Appl. 11: 1641-1655.

Maestre, F. T., Bautista, S., Cortina J. et al. 2002b. Microsite and mycorrhizal inoculum effects on the establishment of Quercus coccifera in a semi-arid degraded steppe. - Ecol. Eng. 19: 289-295.

Maestre, F. T., Bautista, S. and Cortina, J. 2003a. Positive, negative, and net effects in grass-shrub interactions in Mediterranean semi-arid grasslands. - Ecology 84: 3186-3197.

Maestre, F. T., Cortina, J., Bautista, S. et al. 2003b. Small-scale environmental heterogeneity and spatio-temporal dynamics of seedling establishment in a semi-arid degraded ecosystem. - Ecosystems 6: 630-643.

Maestre, F. T., Cortina, J. and Vallejo R. 2006. Are ecosystem composition, structure and functional status related to restoration success? A test from semi-arid Mediterranean steppes. - Restor. Ecol. 14: 258-266.

Maestre, F. T., Huesca, M. T., Zaady, E. et al. 2002a. Infiltration, penetration resistance and microphytic crust composition in contrasted microsites within a Mediterranean semi-arid steppe. - Soil Biol. Biochem. 34: 895898.

Maestre, F. T., Escudero, A., Martínez, I. et al. 2005a. Does spatial pattern matter to ecosystem functioning? Insights from biological soil crusts. - Funct. Ecol. 19: 566-573.

Maestre, F. T., Rodríguez, F., Bautista, S. et al. 2005b. Spatial associations and patterns of perennial vegetation in a semiarid steppe: a multivariate geostatistics approach. - Plant Ecol. 179: 133-147.

Martínez, I., Escudero, A., Maestre, F. T. et al. 2006. Small-scale patterns of abundance of mosses and lichens forming biological soil crusts in two semi-arid gypsum environments. - Aus. J. Bot. 54: 339-348.
Martínez-Sánchez, J. J., Casares-Porcel, M., Guerra, J. et al . 1994 A special habitat for bryophytes and lichens in the arid zones of Spain. - Lindbergia 19: 116-121.

Monzeglio, U. and Stoll, P. 2005. Spatial patterns and species performances in experimental plant communities. - Oecologia 145: 619-628.

Noy-Meir, I. 1973. Desert ecosystems: environment and producers. - Ann. Rev. Ecol. System. 4: 25-51.

Pacala, S. W. and Deutschman, D. H. 1995. Details that matter: the spatial distribution of individual trees maintains forest ecosystem function. - Oikos 74: 357-365.

Padilla, F. and Pugnaire, F. I. 2006. The role of nurse plants in the restoration of degraded environments. - Front. Ecol. Environ. 4: 196-202.

Pausas, J. G., Bladé, C., Valdecantos, A. et al. 2004. Pines and oaks in the restoration of Mediterranean landscapes of Spain: New perspectives for an old practice: a review. - Plant Ecol. 171: 209-220.

Perry, J. N. 1995. Spatial analysis by distance index. - J. Anim. Ecol. 64, 303-314.

Perry, J. N., Winder, L., Holland, J. M. et al. 1999. Red-blue plots for detecting clusters in count data. - Ecol. Lett. 2: 106-113.

Perry, J. N., Liebhold, A. M., Rosenberg, M. S. et al. 2002. Illustrations and guidelines for selecting statistical methods for quantifying spatial pattern in ecological data. - Ecography 25: 578-600.

Prasse, R. and Bornkamm, R. 2000. Effect of microbiotic soil surface crusts on emergence of vascular plants. - Plant Ecol. 150: 65-75.

Puigdefábregas, J. and Sánchez, G. 1996. Geomorphological implications of vegetation patchiness on semi-arid slopes. - In: Anderson, M. G. and Brooks, S. M. (eds.), Advances in Hillslope Processes, volume 2. John Willey \& Sons Ltd, pp. $1027-1060$.

Puigdefabregas, J., Solé-Benet, A., Gutiérrez, L. et al. 1999. Scales and processes of water and sediment redistribution in drylands: results from the Rambla Honda field site in Southeast Spain. - Earth Sci. Rev. 48: 39-70.

Ramírez, D. A. 2006. Estudio de la transpiración del esparto (Stipa tenacissima L.) en una cuenca del semiárido alicantino: un análisis pluriescalar. - PhD. Thesis. Universidad de Alicante, Alicante.

Reynolds, J. F. and Stafford-Smith, M. (eds). 2002. Global Desertification: Do Humans Cause Deserts? - Dahlem University Press, Berlin.

Reynolds, J. F., Virginia, R., Kemp, P. R. et al. 1999. Impact of drought on desert shrubs: Effects of seasonality and degree of resource island development. - Ecol. Monogr. 69: 69-106.

Reynolds, J. F., Maestre, F. T., Huber-Sannwald, E. et al. 2005. Aspectos socioeconómicos y biofísicos de la desertificación. Ecosistemas 2005/3 (URL: http:// w w w. revist a e cosis t e mas.ne t/ articulo.asp? Id=131\&Id_Categoria=2\&tipo=portada).

Sánchez, G. 1995. Arquitectura y dinámica de las matas de esparto (Stipa tenacissima L.), efectos en el medio e interacciones con la erosion. - PhD. Thesis. Universidad Autónoma de Madrid, Madrid.

Schmid, B. and Harper, H. L. 1985. Clonal growth in grassland perennials. I. Density and pattern-dependent competition between plants with different growth forms. - J. Ecol. 73: 793-808. 
Seghieri, J., Galle, S., Rajot, J. L. et al. 1997. Relationships between soil moisture and growth of herbaceous plants in a natural vegetation mosaic in Niger. - J. Arid Environ. 36: 87-102.

Shepherd, U. L., Brantley, S. L. and Tarleton, C. A. 2002. Species richness and abundance patterns of microarthropods on cryptobiotic crusts in a pinon-juniper habitat: a call for greater knowledge. - J. Arid Environ. 52: 349-360.

Stoll, P. and Prati, D. 2001. Intraespecific aggregation alters competitive interactions in experimental plant communities. Ecology 82, 319-327.

Tilman, D. and Kareiva, P. (eds). 1997. Spatial Ecology: The Role of Space in Population Dynamics and Interspecific Interactions. - Princeton University Press, Princeton.

Tirado, R. and Pugnaire, F. I. 2003. Shrub spatial aggregation and consequences for reproductive success. - Oecologia 136: 296-301.

Tongway, D. J., Cortina, J. and Maestre, F. T. 2004. Heterogeneidad espacial y gestión de medios semiáridos. - Ecosistemas 2004/1 (URL: http://www.aeet.org/ecosistemas/041/ revision $5 . \mathrm{htm})$.

Tongway, D. J., and Ludwig, J. A. 1994. Small-scale resource heterogeneity in semi-arid landscapes. - Pacific Cons. Biol. 1: 201-208.

Valentin, C. 1994. Surface sealing as affected by various rock fragment covers in West Africa. - Catena 23: 87-98.

Valentin, C. and Bresson, L. M. 1992. Morphology, genesis and classification of soil crusts in loamy and sandy soils. - Geoderma 55: 225-245.
Valentin, C., d'Herbes, J.M. and Poesen, J. 1999. Soil and water components of banded vegetation patterns. - Catena 37: 124.

Veenendal, E. M., Ernst, W. H. O and Modise, G. S. 1996. Effect of seasonal rainfall pattern on seedling emergence and establishment of grasses in a savanna in south-eastern Botswana. - J. Arid Environ. 32: 305-317.

Wallace, A., Romney, E. M. and Hunter, R. B. 1980. The challenge of a desert: revegetation of disturbed desert lands. Great Basin Nat. Mem. 4: 214-225.

Webster, R. and Boag, B. 1992. Geostatistical analysis of cyst nematodes in soil. - J. Soil Sci. 43: 583-595.

Webster, R. and Maestre, F. T. 2004. Spatial analysis of semi-arid patchy vegetation by the cumulative distribution of patch boundary spacings and transition probabilities. - Environ. Ecol. Stat. 11: 257-281.

West, N. E. 1990. Structure and function of mycrophytic soil crusts in wildland ecosystems of arid to semi-arid regions. Adv. Ecol. Res. 20: 179-223.

Whisenant S. G. 1999. Repairing damaged wildlands. - Cambridge University Press, Cambridge.

Whitford, W. G. 2002. Ecology of Desert Systems. - Academic Press, London.

Wu, X. B., Thurow, T. L. and Whisenant, S. G. 2000. Fragmentation and changes in hydrologic function of tiger bush landscapes, south-west Niger. - J. Ecol. 88: 790-800.

Yanes, M. 1993. La estepa giennense: crónica de una agonía. Quercus 94: 12-15. 